
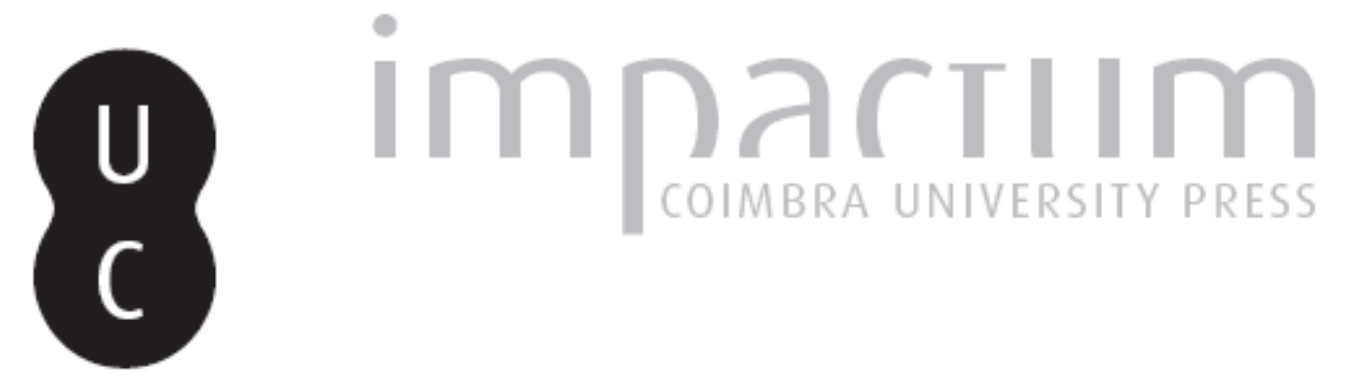

\title{
A Torre de Centum Celas (Belmonte): uma villa romana
}

Autor(es): $\quad$ Frade, Helena

Publicado por: Imprensa da Universidade de Coimbra

URL persistente:

URI:http://hdl.handle.net/10316.2/45478

DOI:

DOI:https://dx.doi.org/10.14195/1647-8657_32_33_4

Accessed : $\quad$ 26-Apr-2023 15:17:11

A navegação consulta e descarregamento dos títulos inseridos nas Bibliotecas Digitais UC Digitalis, UC Pombalina e UC Impactum, pressupõem a aceitação plena e sem reservas dos Termos e Condições de Uso destas Bibliotecas Digitais, disponíveis em https://digitalis.uc.pt/pt-pt/termos.

Conforme exposto nos referidos Termos e Condições de Uso, o descarregamento de títulos de acesso restrito requer uma licença válida de autorização devendo o utilizador aceder ao(s) documento(s) a partir de um endereço de IP da instituição detentora da supramencionada licença.

Ao utilizador é apenas permitido o descarregamento para uso pessoal, pelo que o emprego do(s) título(s) descarregado(s) para outro fim, designadamente comercial, carece de autorização do respetivo autor ou editor da obra.

Na medida em que todas as obras da UC Digitalis se encontram protegidas pelo Código do Direito de Autor e Direitos Conexos e demais legislação aplicável, toda a cópia, parcial ou total, deste documento, nos casos em que é legalmente admitida, deverá conter ou fazer-se acompanhar por este aviso.

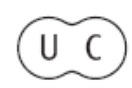




\section{UNIVERSIDADE DE COIMBRA \\ FACULDADE DE LETRAS}

\section{CONIMBRIGA}

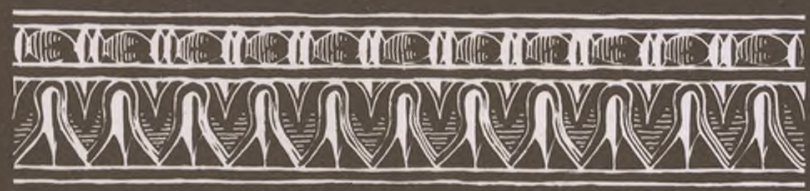

VOLUMES XXXII-XXXIII-1993/94 
HELENA FRADE

Técnica Superior da Direcção Regional de Coimbra do IPPAR

A TORRE DE CENTUM CELAS (BELMONTE):

UMA VILLA ROMANA

«Conimbriga» XXXII-XXXIII (1993-1994), p. 87-106

Resumo: Apresenta-se o resultado das escavações efectuadas na Torre de Centum Celas (Belmonte) em 1993 e 1994. A planta de que hoje se dispõe e os dados da estratigrafía e do espolio permitem concluir que se trata de urna villa romana, cujo proprietário estaria ligado à exploração e comercialização do estanho. Foi construída nos inícios do séc. I e sofreu um incêndio nos finais do séc. Ill, que a destruiu bastante, pois todas as estruturas de madeira desapareceram.

RÉSUMÉ: L'auteur présente ici les résultats des fouilles conduites à Centum Celas (Belmonte) en 1993 et 1994. Le plan, la stratigraphie et les diverses trouvailles permettent de dire qu'il s'agit d'une villa, dont le propriétaire faisait l'exploitation et le commerce de l'étain. Bâtie au 1er siècle elle a été détruite à la fin du Illème, par un grand incendie, qui a brûlé toute la charpenterie.

Conimbriga, 32-33 (1993-1994), 87-106 
(Página deixada propositadamente em branco) 


\title{
A TORRE DE CENTUM CELAS (BELMONTE): UMA VILLA ROMANA
}

\author{
este céu não existe foi inventado hoje \\ sob uma cópia antiga foi num azul assim \\ que um dia no passado algo aconteceu
}

Jorge Guimarães, A Boca de Palavras

A "Torre de Centum Celas" pertence administrativamente ao distrito de Castelo Branco, concelho de Belmonte, freguesia do Colmeal da Torre, e localiza-se numa pequena colina com cerca de $497 \mathrm{~m}$ de altitude.

$\mathrm{O}$ acesso a Centum Celas faz-se utilizando a estrada que, no sítio da Catraia da Torre, surge do lado direito da EN 15, no sentido Covilhã/Guarda, e que se dirige à povoação do Colmeal da Torre. Depois de andadas algumas dezenas de metros na direcção desta localidade, vemos surgir ao nosso lado direito a Torre de Centum Celas, um dos mais representativos e mais enigmáticos monumentos da época romana na Beira Interior.

O edifício está orientado a Nordeste (1) e da sua planta conhecem-se hoje muitas mais estruturas, que se encontravam soterradas, e que as duas campanhas de escavações arqueológicas levadas a cabo no local já permitiram pôr a descoberto.

(1) Apesar de o edifício se encontrar orientado a Nordeste, considerámos a fachada como estando orientada a Norte, pois torna-se mais fácil a descrição das estruturas e do monumento. 
A Torre de Centum Celas, também conhecida como Torre de S. Cornélio, localiza-se numa zona fértil, do ponto de vista agrícola. Está muito perto da confluência da Ribeira de Gaia com o Rio Zêzere, cujas aluviões metalíferas foram explorados desde épocas recuadas.

O topónimo Torre é certamente devido ao aspecto turriforme que as estruturas mais altas do edifício apresentam.

Centum Celas aparece-nos referida como Centocelas em documentos desde o séc. XII. É o nome de uma das povoações existentes num território que D. Sancho I cedeu à Sé de Coimbra, e é também a esta povoação que o bispo D. Pedro dá foral, em 1194. Em 1199

D. Sancho I, em acordo com o referido bispo D. Pedro, retira o poder municipal a Centocelas e dá foral a Belmonte, dando-lhe como limites territoriais os anteriormente estabelecidos para Centocelas (DiAs, 1972).

Estes dois documentos são suficientes para inferir da existência de uma povoação mais antiga, que teria alguma importância, e que o bispo D. Pedro tentou restaurar e repovoar. Era esta, aliás, a prática corrente no início da Nacionalidade, em que através das cartas de foral se tentava restaurar e repovoar aglomerados urbanos já existentes, a par com a fundação de novas localidades.

A Torre poderia estar nas imediações de Centocelas mas sem fazer parte da povoação, que se sabe ter existido algures nas proximidades.

A importância de Centocelas na época da Reconquista estará, certamente, relacionada com a sua localização perto da via romana Mérida - Braga, que continuou a ser utilizada como caminho principal durante bastante tempo (MANTAS, 1990a: 222).

A transferência do poder municipal para Belmonte poderá ter sido motivada por razões estratégicas. Este procedimento parece ter sido usual na época, uma vez que, sensivelmente na mesma altura, foi dado foral a Idanha-a-Nova, situada em local que permitia uma melhor defesa e vigilância, em detrimento de Idanha-a-Velha, localizada na planície e mais vulnerável aos ataques (DiAs, 1972).

Muitos têm sido os autores que ao longo dos tempos se têm referido à Torre de Centum Celas e ao mesmo tempo têm sido propostas as mais díspares funções.

Pinho Leal, em 1874 atribui ao "exquisito edifício" as funções de atalaia reedificada por D. Dinis. Refere a sua fundação romana e a existência de "uma pequena povoação" em seu redor. 
Vergilio CORREIA (1928: 266) supõe tratar-se de um santuário isolado, de fundação romana.

Para o General João de AlmEIDA (1945: 406-408), adoptando acriticamente a tradição popular, a Torre seria a prisão onde esteve encarcerado o Papa S. Cornélio.

Adriano Vasco Rodrigues (1962: 319-325) liga o monumento com a via romana que passa perto e diz tratar-se do praetorium de um acampamento romano.

Manuel J. Calais (1984: 16-17) estudou a arquitectura do edifício e encontrou para ele paralelos em construções egípcias e gregas. Defende tratar-se de um templo, utilizado pelos romanos com fins não religiosos.

Aurélio Ricardo Belo, que realizou escavações no local, relaciona o edifício com a via romana, dizendo tratar-se de uma mansio fortificada (BELo 1964: 140 e 1966: 25-35).

Jaime Lopes DiAs (1972: 31), após fazer o ponto da situação das diversas opiniões sobre Centum Celas, propõe que seja o que resta de uma cidade romana que ali existiu.

Recentemente, Jorge de AlarCão (1988: 4/301) lançou nova hipótese sobre a funcionalidade da Torre. Refere que poderá ser parte integrante de uma villa e que o resto do edifício terá sido destruído.

Vasco MAnTAS considera a Torre de Centum Celas como uma mansio (1990a: 226) ou uma mutatio da via romana Mérida - Braga (1990b).

As escavações, efectuadas por Aurélio Ricardo Belo no final da década de 50, permitem-nos situar a utilização do edifício, durante a época romana, desde o séc. I ao séc. IV-V (LEITÃo, 1980: 104).

Nós próprios, em Maio de 1990, nos referimos a este monumento salientando que de "todas as propostas de utilização que têm sido apresentadas, poder-se-ão pôr de parte algumas, uma vez que as ruínas actualmente visíveis dificilmente nelas se poderiam integrar. Não basta olhar as ruínas em si; será necessário integrá-las no mundo mais vasto e complexo que seria a Cova da Beira ao tempo da romanização, relacionando-as com todos os vestígios actualmente conhecidos.

Inscrições romanas, cerâmicas, moedas e restos de edifícios, assinalados nas freguesias de Vale Formoso, Orjais e Belmonte, poderão ser os vestígios de estabelecimentos romanos implantados junto da via que de Mérida se dirigia a Braga. Neste contexto, Centum Celas será, certamente, mais um desses locais que, tal como hoje, se erguem 
junto das estradas. Sendo mansio ou mutatio, ligada ao sistema público de transportes, seria interessante saberem-se quais os tempos de viagem gastos, quer de Idanha-a-Velha a Centum Celas, quer na subida da Serra da Estrela. Mas mesmo que o tempo gasto entre Idanha e este local não justificasse uma paragem, sempre se poderá pôr a hipótese que seria a última paragem onde os viajantes descansariam antes da subida da Serra.

Poderia igualmente ter sido um edifício que não estivesse directamente relacionado com a estrada. Seria então uma villa, de que se conservou parte do edifício cujas paredes têm ainda hoje uma altura pouco habitual" (FRADE 1990).

Convém aqui lembrar a descrição feita por Manoel Pereira da Sylva Leal, que nos descreve as ruínas que visitou em 1762 e que diz não terem qualquer semelhança com uma prisão ou uma torre, mas sim parecerem-se antes com as ruínas de um palácio ou uma casa de campo, e que ele, no entanto, diz não terem a antiguidade que lhe atribuem. (LEAL 1779: 340-341).

Pela localização do monumento é possível que ele esteja relacionado com os trabalhos de exploração de cassiterites efectuados, na época romana, no Vale do Zêzere e mais concretamente na Ribeira de Gaia. É de referir que, quando no início deste século se procedeu à dragagem dos aluviões, se encontraram várias moedas romanas, tendo sido algumas delas examinadas no Museu Britânico e atribuídas ao séc. I (Allan 1965: 15).

As prospecções electromagnéticas efectuadas junto da Torre de Centum Celas, em meados da década de 80, não forneceram novos elementos sobre a localização de muros soterrados (Monteiro e MATIAS 1987: 125-127).

As escavações arqueológicas iniciadas em $1993 \quad{ }^{(2)}$ na Torre de Centum Celas não aparentavam, à partida, poder vir a fornecer muitas

(2) Cabe aqui um agradecimento a todos quantos tornaram possíveis os trabalhos arqueológicos em Centum Celas. Não querendo ser exaustivos, e apesar de sabermos que mesmo involutariamente poderemos omitir alguém, queremos expressar a nossa profunda gratidão a toda a população do Colmeal da Torre, e em especial àqueles que vivendo mais perto da Torre, pelo carinho e compreensão que tiveram e sobretudo pela atenção e vigia que fizeram do sítio e do monumento, durante e após as campanhas de escavação; aos jovens de Belmonte e do Colmeal da Torre que, sob o sol escaldante, deram muito do seu esforço e suor para tornar realidade esta escavação; ao Dr. António Augusto Marques, arqueólogo da Câmara Municipal de Belmonte, que sempre esteve 
informações sobre a planta do edifício (fot. 1). No entanto, hoje e após duas campanhas de escavação ( ${ }^{3}$ ) efectuadas em 1993 e 1994, podemos retirar algumas conclusões sobre a planta, a história e a funcionalidade das ruínas da Torre de Centum Celas $\left({ }^{4}\right)$.

\section{Os vestígios arqueológicos}

O que hoje vemos da Torre de Centum Celas são os restos de um edifício, construído com silharia de boa fábrica romana, com pequenos acrescentos na parte superior feitos com pedras quadradas, que se encontram a colmatar e a fechar espaços que funcionaram como aberturas no primitivo edifício.

Para uma maior facilidade de descrição e de trabalho, às diversas paredes ou apenas aos registos que delas nos ficaram foi atribuído um número árabe; os diversos espaços definidos pelas paredes foram numerados com números romanos, quer se tratasse de salas, pátios abertos ou simples corredores de passagem.

Nem todas as salas que numerámos foram totalmente postas a descoberto, mas apresentavam já algumas paredes visíveis, o que nos permitiu atribuir-lhe uma numeração.

ao nosso lado partilhando connosco quer os problemas de rotina da escavação quer as alegrias e a euforia de cada uma das descobertas; ao Dr. José Luís Madeira e a José Augusto Alves Dias, desenhadores da Direcção Regional do IPPAR, que desenharam e atintaram os diversos levantamentos e cortes estratigráficos; à D. Teresa e ao Sr. José Calheiros pela disponibilidade e amabilidade que sempre demonstraram quando a eles recorríamos; à Junta de Freguesia, actual e anterior, agradecemos na pessoa dos seus presidentes o incentivo e apoio que sempre nos deram; ao Sr. António Júlio Garcia, ex-Presidente da Câmara Municipal e ao Dr. António Pinto Rocha, Presidente da Câmara de Belmonte e ao Sr. Amândio Melo, vereador municipal, agradecemos o apoio logístico prestado e a amizade calorosa com que sempre nos receberam.

(3) A torre de Centum Celas encontra-se classificada como Monumento Nacional pelo Decreto Lei 129/77 de 29 de Setembro de 1977, e é um monumento afecto ao IPPAR. As fracturas existentes nalguns silhares do imóvel podem colocar em risco a estabilidade do edifício. As escavações arqueológicas que se têm vindo a realizar no local visam um melhor e mais completo conhecimento do sítio e da sua história, para posteriormente se poder elaborar um projecto de recuperação e valorização desta importante estação arqueológica

$\left({ }^{4}\right)$ Não podemos deixar de aqui fazer uma referência especial ao Prof. Doutor Jorge Alarcão, pelo apoio científico, disponibilidade e incentivo que sempre nos deu, e ao Prof. Theodor Hauschild pelas reflexões e sábias sugestões que nos fez.

Conimbriga, 32-33 (1993-1994), 87-106 
O aspecto exterior da Torre poderá levar-nos a pensar que ela teria originalmente tido três andares. Contudo, uma análise das paredes interiores do edifício, a nível do $1 .^{\circ}$ andar, permitiu-nos constatar que não há indícios de que a primitiva planta do monumento tivesse um $3 .^{\circ}$ piso. As janelas que existem na parte superior das paredes, e que ainda mantêm a feição original na parede Sul, serviam certamente para dar luz a uma ampla e única sala que existia no $1 .^{\circ}$ andar. Nas paredes interiores e ao nível do $1 .^{\circ}$ andar também não se notam quaisquer vestígios de arranques de outras paredes que pudessem ter servido para compartimentar esta grande sala, razão que nos leva a propô-la como um espaço único.

Por uma questão metodológica e de maior facilidade na exposição pensamos ser mais correcto passarmos a fazer uma descrição de cada um dos espaços.

\section{SALAI}

Esta sala encontrava-se praticamente limpa e é delimitada pelos muros 13, 16, 9 e 15, situados respectivamente a Nascente, a Norte, a Poente e a Sul.

Apresenta duas portas que lhe dão acesso: uma, virada a nascente com acesso ao corredor XVI, e uma outra que a ligava à sala V, no rés-do-chão da Torre. Parece não ter tido ligação directa com a sala II.

\section{SALA II}

Esta sala encontrava-se ainda com bastante terra, tendo por essa razão conservado as suas paredes com maior altura do que a sala I.

É delimitada pelos muros 13, 15, 9 e 14, situados respectivamente a Nascente, a Norte, a Poente e a Sul. Possui uma porta que dá acesso à sala III e outra que liga directamente ao corredor XXV, existente no interior da Torre.

\section{SALA III}

Encontrava-se praticamente cheia de terra, pelo que de todas é a possui as paredes melhor conservadas e com maior altura.

É delimitada pelos muros 13, 14, 9 e 12, situados respectivamente a Nascente, a Norte, a Poente e a Sul. Não possui qualquer acesso directo ao interior da Torre a não ser duas janelas para iluminação. $\mathrm{O}$ acesso a esta sala era feito através da porta que a liga com a sala II. Os muros 13 e 9 não são construídos apenas com grandes silhares, pois apresentam de onde em onde alguns espaços preenchidos com blocos 
mais pequenos. Estes estão perfeitamente integrados e imbricados na estrutura global do muro, pelo que pensamos não se tratar de arranjos posteriores mas antes de uma técnica construtiva correspondente à primitiva construção (fot. 2).

\section{SALA IV}

Esta sala estava praticamente limpa, pois aqui procedemos apenas a uma pequena raspagem da terra que se foi acumulando ao longo dos anos. Trata-se de uma área muito conturbada, existindo um pouco por todo o lado buracos feitos no afloramento granítico, em busca do tesouro que a lenda diz existir junto da porta $100\left(^{5}\right)$. Também o hábito de fazerem fogueiras e piqueniques no interior do monumento foi bastante nocivo para o entendimento dos níveis arqueológicos que pudessem ter sido deixados, após a limpeza feita em época anterior às escavações do Dr. Aurélio Ricardo Belo, na década de 50.

É delimitada pelos muros 9, 10, 2 e 1, situados respectivamente a Nascente, a Norte, a Poente e a Sul. Está situada no limite Sul do rés-do-chão da Torre e o corredor XXV, situa-se-lhe a Norte. É possível que este espaço tenha sido subdividido em dois, o que tentaremos confirmar durante os trabalhos de 1995, com uma análise mais atenta dos registos dos arranques de paredes existentes na face interna da Torre.

Tem acesso ao corredor XXV por duas portas. Delas temos ainda uma soleira de granito, em muito bom estado, situada no ângulo poente da parede 2 com a parede 10, além do registo deixado no solo de base e das marcas das cunhas que permitiram o seu arranque, junto da parede 9.

Existem ainda janelas que davam arejamento e iluminação a este espaço, situadas nas paredes 1,2 e 9.

\section{SALA V}

Este espaço encontrava-se praticamente limpo, tendo-se aqui apenas procedido a uma pequena decapagem das terras acumuladas sobre o afloramento granítico. Também aqui se encontraram e se notaram as perturbações já referidas quando tratámos da sala IV.

É delimitada pelos muros 9, 8, 2 e 11, situados respectivamente a Nascente, a Norte, a Poente e a Sul. Do muro 11, que limita a Norte o

${ }^{(5)} \quad$ Segundo a lenda existe escondido junto da porta número 100 do edifício um tesouro. É em busca deste tesouro que terão sido abertas, no afloramento granítico, várias covas.

Conimbriga, 32-33 (1993-1994), 87-106 
corredor XXV, apenas temos o registo do seu arranque na face interior das paredes Nascente e Poente da Torre.

Esta sala apresenta três portas na parede 8, que dão acesso ao corredor XVI, as quais são encimadas por três pequenas aberturas para iluminação e arejamento. Tem ainda ligação com as salas I e VI através de portas e apresenta ainda uma janela que dá para a sala VI.

\section{SALA VI}

Este espaço encontrava-se praticamente limpo e bastante destruído. É delimitado pelos muros 2, 7, 4 e 6, situados respectivamente a Nascente, a Norte, a Poente e a Sul. À excepção do muro 2, ainda em bom estado, os outros encontram-se bastante destruídos, com os silhares de granito já desaparecidos ou apenas reduzidos ao silhar de base do muro.

Apresenta uma porta de acesso à sala IV e uma janela virada para a mesma sala, rasgada no muro 2. Relativamente à comunicação desta sala com a sala VII, é possível que não existisse e a sua planta fosse muito semelhante ao que atrás descrevemos para a sala I. Devido ao estado de destruição dos muros 7 e 4, no canto noroeste, pouco poderemos adiantar, com segurança, relativamente à sua estrutura.

\section{SALA VII}

Encontrava-se praticamente limpa. A terra que se acumulou naturalmente foi retirada e verificou-se que havia uma zona com terra mais escura, dentro de um buraco aberto no afloramento granítico. Esta terra foi cuidadosamente retirada e verificou-se ser um enchimento recente de mais uma das muitas covas abertas em busca do lendário tesouro.

É delimitada pelos muros 2, 6, 4 e 5, situados respectivamente a Nascente, a Norte, a Poente e a Sul. Do mesmo modo como sucedia na sala II, já descrita, também aqui existe uma porta de acesso ao corredor XXV e uma outra de acesso à sala VIII.

\section{SALA VIII}

Esta sala tinha no seu interior vários silhares, resultantes de derrubes, bem como um fragmento do ângulo esquerdo do frontão que coroava a parede Sul do edifício. É este, até ao momento, o único elemento arquitectónico que possuímos relativo à cobertura da parte superior do edifício. 
É delimitada pelos muros 2, 5, 4 e 3, situados respectivamente a Nascente, a Norte, a Poente e a Sul. Apresenta uma porta de acesso à sala VII e uma janela rasgada na parede 2 , que dá para a sala IV.

\section{SALA IX}

Encontrava-se completamente enterrada. Nela encontrámos vários silhares de grandes dimensões, fora do seu local de origem, bem como fragmentos dos frisos exteriores que depois de partidos nunca foram removidos do local. Além destas pedras há ainda a referir camadas de destruição com tegulae e imbrices, bem como pedras miúdas resultantes dos desmontes dos muros para reutilização dos materiais.

É delimitada pelos muros 21, 23, 22 e 18, situados respectivamente a Nascente, a Norte, a Poente e a Sul. Apesar de não haver qualquer registo de soleira e de a parte Sul do muro 22 ter apenas o registo do assentamento do silhar, pensamos que um dos acessos a esta sala se faria pelo canto Sudoeste, fazendo assim ligação directa ao corredor XVI e às escadas que se encontram a Sul do muro 18, e encostadas a ele.

Havia uma outra entrada para esta sala, pois temos ainda o registo de uma soleira no muro 22, onde ainda se nota o sítio de um gonzo. Esta soleira, que hoje apresenta uma largura muito menor do que aquela que poderia ter tido na sua fase inicial, está sensivelmente ao nível do corredor XVII e da sala XII. Refira-se que esta zona da parede foi bastante alterada, pelo que podemos apenas pôr como hipótese que esta abertura tenha sido primitivamente uma porta, transformada posteriormente numa janela para iluminação e arejamento desta sala.

Nesta sala e junto da parede 23 foi encontrado uma espécie de colector, aberto no afloramento granítico e que se encontrava cheio com pedras, fragmentos de dolia e escórias de ferro. Não sabemos, com segurança, a finalidade desta estrutura, pois poderá estar relacionada com possíveis esgotos (?), detectados na sala $\mathrm{X}$ e ainda não totalmente escavados.

\section{SALAX}

Esta sala encontrava-se totalmente soterrada e na sua maior parte cheia com pedras de várias dimensões, podendo mesmo pensar-se que a maioria delas teria pertencido ao forro do muro 32, que aqui se apresenta totalmente destruído e sem qualquer pedra. Dele apenas temos a vala de fundação no afloramento granítico, que marca a sua continuação para esta sala. 
É delimitada pelos muros 24, 23 e 32 situados respectivamente a Nascente, a Sul e a Poente. Como atrás dissemos, do muro 32 so resta o seu registo e alinhamento, e não possuímos até ao momento o limite Norte desta sala. Foi detectado ainda o muro 25, que numa primeira análise parece pertencer a uma campanha de obras posterior, pois tem alicerces, espessura e um aparelho completamente diferente dos que seguramente atribuímos à primeira fase de obras.

Nesta sala foi ainda detectada uma lareira, que era feita com barro moldado, não cozido e que teria uma configuração mais ou menos oval. Esta lareira estava muito destruída por uma grande e espessa camada de tegulae e imbrices, que lhe caíram em cima e que ao mesmo tempo que a partiram também de algum modo a preservaram. Refira-se que a camada de tegulae e imbrices aqui detectada apresenta a sua parte superior sensivelmente ao nível do que resta dos muros romanos.

\section{SALA XI}

Estava completamente enterrada e ainda não foi concluída a sua escavação. A parte nascente desta área apresenta-se bastante conturbada, sendo bem visíveis os níveis de pedras provenientes das destruições de muros e condutas. É provável que esta destruição tenha sido devida, em grande parte, à descoberta de um dolium inteiro nos anos 50, que foi desenterrado neste local e que hoje se encontra no Porto.

As dimensões desta sala são bastante problemáticas devido a haver muros pertencentes a mais do que uma época, mas nesta fase dos trabalhos poder-se-á talvez considerar como limites prováveis os muros 34, 21 e 23, situados respectivamente a Sul, a Poente e a Norte.

O muro 55, a Norte, encontra-se interrompido e a área por onde se poderá prolongar ainda não foi escavada, pelo que o indicamos aqui como limite, embora não sem algumas reservas. O limite Nascente deverá situar-se sob a banquete Este, ainda não escavada, se atendermos a que foi assinalado um pátio exterior a nascente desta sala, o espaço a que demos o número XXIV.

Esta sala tem duas condutas, construídas com pedras postas de cutelo e cobertas por lajes de granito, e uma lareira feita com tijoleiras, de forma rectangular (fot. 3). As tijoleiras encontram-se colocadas na vertical à volta da lareira, e estão dispostas horizontalmente no sítio onde era feito o lume. 


\section{SALA XII}

Este espaço situa-se a Nascente da Torre e dele apenas podemos dizer que poderá ter sido um pátio aberto. Ainda não está completamente escavado sendo limitado a Sul pelo corredor XVI, a Nascente pelo corredor XVII e pelo muro 20, e a Poente pelo muro 40. No alinhamento do muro 19, que separa esta sala do corredor XVI, foram encontrados os alicerces de duas possíveis pilastras que serviriam para suportar o varadim que terá existido à volta da Torre, no $1 .^{\circ}$ andar (fot. 4).

Durante a escavação desta zona foi detectada uma camada de destruição, que conservou no seu seio, para lá dos mais diversos materiais, dois fragmentos de fuste de coluna e um capitel toscano (fot. 5). Estes elementos terão certamente pertencido ao varandim do $1 .^{\circ}$ andar, em grande parte construído com madeira e destruído por um incêndio, se atendermos aos carvões e à cor da terra que formava a camada de destruição.

\section{SALA XIII}

Esta sala é um amplo espaço limitado pelos muros 13, 28 36, 16 e 27 respectivamente a Poente, a Sul, a Nascente e a Norte. Entre o muro 16/17 e o muro 27 existia uma grande quantidade de pedras envoltas em terra preta, que pela sua disposição poderão corresponder ao enchimento deste espaço, e onde provavelmente se situava a continuação da escada que daria acesso ao varandim do $1 .^{\circ}$ andar (fot. 6).

O limite nascente desta sala é, certamente, no local assinalado com o número 36. Este muro, por se encontrar perto de um caminho, foi totalmente destruído, restando apenas parte da vala de fundação feita no afloramento granítico, parcialmente cheio com pedras miúdas, previamente mexidas.

Neste espaço foram assinalados muitos restos cerâmicos e vários dolia de dimensões razoáveis. Dois deles tinham ainda o fundo e parte do bojo e estavam sobre o afloramento granítico.

\section{SALA XIV}

Apresenta as paredes bastante destruídas encontrando-se algumas delas reduzidas às pedras de enchimento dos caboucos ou apenas registadas na fundação escavada no afloramento granítico. Os limites desta sala são os muros 31,37 e 29, respectivamente a Nascente, a Sul e a Norte. O limite Poente desta sala ainda não está, de momento, perfeitamente definido. 
A escavação deste espaço forneceu bastante cerâmica fina, pesos de tear e algumas mós manuais, bem como inúmeros fragmentos de dolia.

\section{SALA XV}

Situa-se a Sul da sala XI e poderá ser apenas o resultado de obras levadas a efeito neste local, que a subdividiram.

A escavação neste espaço ainda não foi completada, pelo que os elementos recolhidos são insuficientes para que possamos tecer grandes considerações sobre ele.

\section{CORREDOR XVI}

A potência estratigráfica assinalada neste espaço era pequena e não nos forneceu grandes informações.

Este corredor era um importante espaço de circulação e permitia o acesso a várias salas.

\section{CORREDOR XVII}

Situa-se entre a sala IX e a sala XII e ainda não o conhecemos na sua globalidade, pelo que só a continuação das escavações nos permitirá tecer comentários mais seguros sobre ele.

\section{SALA XVIII}

Desta sala apenas conhecemos parte dos muros 39 e 38, que a delimitavam a Nascente e a Sul. Foi definida pelos rasgos abertos no solo de base, e foi possível reconstituir a largura das suas paredes através de um grande bloco de granito que se encontra no ângulo sudeste da sala.

\section{SALA XIX}

Esta sala encontra-se apenas limitada e definida pelas valas feitas no afloramento granítico para implantação dos muros, e que numerámos como 40, 41, 42 e 43. Das pedras que constituíam estas paredes restaram apenas algumas no muro 41, tendo todas as outras desaparecido (fot. 7).

\section{SALA XX}

As paredes 44, 45 e 47 delimitam esta sala, a Nascente, a Sul e a Norte, respectivamente. O muro 46, situado a Poente, é ainda dema- 
siado diminuto para the podermos atribuir essa função. Na parede 47 existe uma soleira de porta e a parte sul da parede 45 encontra-se reduzida a um simples rasgo no solo de base, não havendo já qualquer vestígio de pedras (fot. 8).

\section{SALA XXI}

Esta sala está delimitada pelos muros 56,47 e 48, respectivamente a Nascente, Sul e a Norte. A soleira, existente no muro 56 tem grandes dimensões, ocupando toda a largura deste compartimento. Não existe ainda o limite poente deste espaço (fot. 8).

\section{SALAS XXII e XXIII}

Estas duas salas conservam paredes com uma altura bastante considerável, mas ainda não foram completamente escavadas.

Os muros 53 e 54 são provavelmente construções posteriores à grande destruição motivada pelo incêndio que danificou o edifício primitivo.

\section{SALA XXIV}

Os limites deste espaço estão ainda mal definidos, mas podemos desde já dizer que se trata certamente de uma área exterior do edifício, parcialmente pavimentada com uma pequena calçada de pedras de pequenas e médias dimensões.

\section{CORREDOR XXV}

Este corredor divide a Torre, sensivelmente a meio, no sentido Nascente-Poente e permite o acesso às salas II, IV e VII.

Dele temos os registos dos arranques das paredes 10 e 11, visíveis na parede interior da Torre (fot 9), além de uma soleira e do registo de uma outra.

$\mathrm{O}$ muro 52, que se encontra encostado ao muro 4, faz certamente parte de uma estrutura destinada à contenção de terras, e prolongava-se para poente onde o fomos encontrar já completamente destruído (fot.

10). Pelo seu aparelho não nos parece que tivesse sido construído para poder ficar à vista. Contudo, de momento, não possuímos dados suficientes para o integrar em qualquer estrutura do monumento. A Sul deste muro o afloramento granítico apresenta-se bastante alto, enquanto que na parte Norte havia níveis de terra preta com bastante espólio cerâmico, que se encontravam sobre rasgos abertos no solo de base, e 
que certamente serviam para proporcionar um melhor escoamento das águas.

Pela análise das estruturas detectadas e da sua relação com os diversos níveis arqueológicos e respectivo espolio, podemos retirar algumas conclusões, ainda que não seja demais sublinhar o carácter provisório que têm. Trata-se, antes de mais, de colocar meras hipóteses de trabalho, passíveis de todas as alterações, que poderão ser suscitadas pelo normal desenrolar dos trabalhos de escavação.

Assim, e após estes dois anos de trabalhos arqueológicos na Torre de Centum Celas, podemos desde já colocar como ponto assente que o edifício actualmente visível e conhecido como Torre não se encontrava isolado mas estava inserido num maior e mais complexo conjunto de estruturas. Estas desenvolvem-se a partir da Torre, que parece ser o núcleo central de todas as construções, compreendendo salas fechadas, corredores e espaços abertos ou pátios. A Torre seria o espaço mais alto, e os restantes estavam dispostos em diversos patamares apresentando-se com diferentes alturas e volumetrias.

A Torre, na sua primitiva planta deveria ter apenas rés-do-chão e primeiro andar, tendo a toda a volta um varandim, cujo telhado era suportado pelas paredes 2 e 9 nos lados Poente e Nascente, e pelas paredes 19 e 43, associadas a duas pilastras possivelmente quadradas, a Norte. Para a parte Sul ainda não possuímos elementos suficientes para definir o seu suporte.

Todas as paredes da Torre apresentam um aparelho cuidado, feito com grandes silhares de granito. Ao nível do Io andar, no interior e no exterior, existe uma pequena cornija moldurada, que servia para assentamento da madeira dos pavimentos, e sobre a qual ainda há vestígios do encaixe dos caibros, que os suportavam (fot. 1 e 9).

A parte superior das paredes Norte, Nascente e Poente da Torre tem um aparelho diferente de todo o resto do edifício, constituído por pedras almofadadas. Estas pedras não foram mexidas e certamente pertenceriam ao primitivo edifício. Só se encontram aqui porque esta era a única parte visível do exterior, necessitando assim de ter um tipo de aparelho diferente, mais cuidado, uma vez que a parte inferior das paredes encontrava-se parcialmente encoberta pelo varandim e demais construções.

O varandim possuía colunas, possivelmente colocadas sobre um pequeno muro de pedra, e encimadas por capitéis toscanos. Para este varandim abriam-se todas as portas e janelas hoje visíveis no $1 .^{\circ}$ piso do edifício. 
As janelas que existem na parte superior da parede poente, certamente a melhor conservada, bem como todas as outras que hoje se encontram entaipadas com pedras pequenas, serviam possivelmente para iluminar a única e ampla sala que existia no $10^{\circ}$ andar, e que ocupava todo o espaço do interior da Torre, como atrás já foi referido.

$\mathrm{O}$ acesso a este andar poderia ser feito no espaço compreendido entre as paredes 26 e 17, que seria o normal desenvolvimento das escadas actualmente existentes junto da parede 18, e com o recurso a um pequeno patamar antes da ascensão ao andar superior (fot. 6).

A Torre tinha, possivelmente, um telhado de duas águas e o remate superior das paredes Norte e Sul era feito com um frontão triangular, de que ainda existe um pedaço de um dos seus ângulos.

A rocha é em alguns casos cortada, para servir de cabouco aos muros, sendo os silhares de granito que constituem as paredes encostados (fot. 11) ou colocados no centro (fot. 12) dos rasgos. O espaço existente entre a rocha e a parede é normalmente colmatado com pedras miúdas e terra, formando assim o forro do muro.

A maior parte das paredes feitas com grandes silhares apresentam o silhar de base assente directamente no afloramento granítico, havendo por vezes um ligeiro alisamento e aprofundamento do local em que os silhares vão ser colocados. Em alguns casos verifica-se que a pedra de base é afeiçoada de modo a que a parte inferior, que assenta no solo, seja mais larga, permitindo assim uma melhor descarga de forças e uma maior estabilidade ao edifício (fot. 13).

Nem todos os muros deste monumento apresentam uma construção feita com grandes silhares, (fot. 14), havendo nalguns casos paredes feitas com pedras de menores dimensões (fot. 15). Esta diferença de aparelho não nos parece corresponder a diferentes fases de construção, mas deverá resultar do tipo de descargas que as paredes terão que suportar. Há que lembrar que este edifício não se apresentava todo com a altura da parte central, havendo estruturas e coberturas a níveis diferentes.

A construção deste monumento pode ser situada nos inícios do séc. I d. C. Sofreu um incêndio e uma grande destruição nos finais do séc. III.

O edifício não manteve sempre a mesma estrutura, e é possível que, depois do incêndio que atrás referimos, tenha havido algumas obras de beneficiação e de remodelação dos diferentes espaços. E provável que datem desta época o entaipamento de algumas das janelas da parte 
superior, pois hoje vemos entre as pedras almofadadas, pertencentes à primitiva construção, pequenas pedras quadradas que poderão resultar destas obras. As paredes 25, 53 e 54, construídas sobre camadas de destruição, são também possivelmente resultado desta remodelação.

Como se disse atrás, várias foram as hipóteses colocadas relativamente à funcionalidade deste edifício; no entanto, os últimos estudos publicados, inclinam-se principalmente para duas - Mansio ou Villa. Face às estruturas encontradas e aos dados de que actualmente dispomos, pensamos tratar-se de uma villa, cujo proprietário deveria estar ligado à exploração de estanho, para lá das normais actividades agrícolas.

É de referir que ao longo da escavação e em diferentes níveis estratigráficos foram encontrados vários fragmentos de escória de estanho, que apresentam uma percentagem de estanho muito elevada, superior a $90 \%$, de acordo com as análises efectuadas a alguns fragmentos pelo Dr. Craig Merideth do Instituto de Arqueologia do University College of London.

Reforçando o que atrás dissemos quanto à funcionalidade deste edifício como parte de uma villa, cabe aqui recordar aquilo que nos diz Sylva Leal sobre o que viu na visita que em 1722 efectuou às ruínas do sítio de Centocelas: "... o edificio, que ainda persevera naquelle sitio, o qual dizem ser a Torre, em que esteve prezo o Santo, nem tem fórma de Torre, nem mostra antiguidade, que lhe attribuem, e correndo-o eu todo no anno mil setecentos e vinte e dous, me pareceo, o que ainda delle existe, lanço de hum Palacio, ou casa de campo, com divisaõ de salas, e cameras, e com janellas rasgadas, e altas, estando já ruinadas as mais partes, que com elle continuavaõ ...”.

Continua o mesmo autor: "Nem as ruinas, que junto a elle se divisaõ, saõ indicios de povoaçaõ, que alli houvesse, ... mas de outros lanços daquelle Palacio ruinado, que mais me pareceo casa de campo, que Torre ..." (LeAl 1779: 340-341).

Apesar de lhe podermos atribuir a função de villa, nunca é demais lembrar que a sua localização, tão próximo da estrada romana, foi certamente uma condicionante importante e vital, se pensarmos na exploração do estanho e na necessidade do seu fácil e rápido escoamento.

$\mathrm{O}$ incêndio e a destruição de parte do monumento, que pudemos documentar durante os trabalhos de escavação, poderão estar relacionados com revoltas e conturbações sociais, que se fizeram sentir, nesta zona, nos finais do séc. III. Destas perturbações pouco conhecemos relativamente ao seu impacto e à sua real importância. Contudo, pode- 
rão, de algum modo estar relacionadas com os dois tesouros descobertos no Teixoso e na Borralheira (ALARCÃO 1994: 40), tendo o último deles sido entesourado no séc. III. Só a continuação de escavações sistemáticas em outras villae da Cova da Beira e a sua correcta análise estratigráfica poderá, de algum modo, vir um dia a corroborar ou não a hipótese que levantámos.

\section{BIBLIOGRAFIA}

AlarCão, Jorge de (1983), Portugal Romano, Lisboa.

AlarCão, Jorge de (1988), Roman Portugal, voi. 2(1), 4/301.

AlarCão, Jorge de (1994), Arqueologia da Serra da Estrela, Manteigas.

Allan, John C. (1965), A mineração em Portugal na Antiguidade, "Boletim de Minas", 2(3), p. 137-173.

ALMEIDA, João de (1945), Roteiro dos monumentos militares portugueses, I, Lisboa.

Belo, Aurélio Ricardo (1960), Nótulas sobre cinco marcos miliários da via militar Mérida - Viseu - Braga, encontrados nas proximidades da Torre de Centum Cellae de Belmonte, "Revista de Guimarães", 70(1-2), p. 27-50.

Belo, Aurélio Ricardo (1964), Dois marcos miliários, inéditos, do troço Cellae - VaIhelhas, da via militar romana Mérida - Viseu - Braga, "Arqueologia e História", 8. a série, 11 , p. 128-142.

Belo, Aurélio Ricardo (1966), O problema da Torre de Centum Cellae, de Belmonte, "Arqueologia e História", 8. a série, 12, p. 23-34.

Belo, Aurélio Ricardo (1970), Algumas palavras sobre a Torre de Centum Cellae de Belmonte, "Actas e Memorias do I Congresso Nacional de Arqueologia", Vol. II, p. $35-55$

CALAIs, Manuel João (1984), A geometria de Centum Cellas, Covilhã.

Самасно, Pereira (1957), Belmonte, Lisboa.

Correia, Vergilio (1928), O domínio romano, in Peres, Damião (dir.) História de Portugal, I, Barcelos, p. 215-290.

DiAs, Jaime Lopes (1972), Centum Cellas na arqueologia e na historia luso-romana e portuguesa, "Memorias da Academia das Ciências. Classe de Letras", 15, p. 87-108 .

Frade, Helena (1990), A Torre de Centum Cellas, Belmonte, "Ias Jornadas de Arqueologia da Beira Interior. Actas" (no prelo).

HiPólito, Mário de Castro (1960), Dos tesouros de moedas romanas em Portugal, "Conimbriga", 2-3, p. 1-166.

JalHaY, Eugênio (1950), Inscrições romanas do Museu da Guarda "Brotéria", 50(5), p. $560-572$.

Leal, Augusto de Pinho (1874), Portugal Antigo e Moderno, voi. II, Lisboa.

LEAL, Manoel Pereira da Sylva (1779), Memorias Para A Historia Ecclesiastica do Bispado da Guarda, Tomo Primeiro, Lisboa.

Conimbriga, 32-33 (1993-1994), 87-106 
LeITão, Manuel (1980), Alguns materiais romanos provenientes das escavações do Dr. Aurélio Ricardo Belo em Centum Cellae - Belmonte, "Estudos de Castelo Branco", nova série, 6, p. 98-107.

Mantas, Vasco Gil (1990a), A rede vidria do convento escalabitano, "Actas del Simposio sobre La Red Viaria en la Hispania Romana", Zaragoza, p. 219-239.

Mantas, Vasco Gil (1990b), Teledetecção e vias romanas, "Actas das I Jornadas sobre Teledeteccion y Geofisica aplicadas a la Arqueologia”, Madrid (no preio).

Monteiro, A. J. Nunes e Matias, M. J. Senos (1987), Uso de técnicas de prospecção geofísica em arqueologia - Villa Cardílio e Centum Cellae, "Arqueologia”, 15, p. 122-128.

Proença Júnior, Francisco Tavares de (1910), Archeologia do districto de Castello Branco, Leiria.

Rodrigues, Adriano Vasco (1960), A Torre de Centum Celas, "Primeiro de Janeiro", 18.10.1960.

Rodrigues, Adriano Vasco (1962), A Torre de Centum Celas, Pretório de um acampamento romano?, "Revista de Guimarães", 72(3-4), p. 319-325

Tavares, J. Cardoso (1974), Subsídios para uma monografia da vila de Belmonte, Belmonte. 


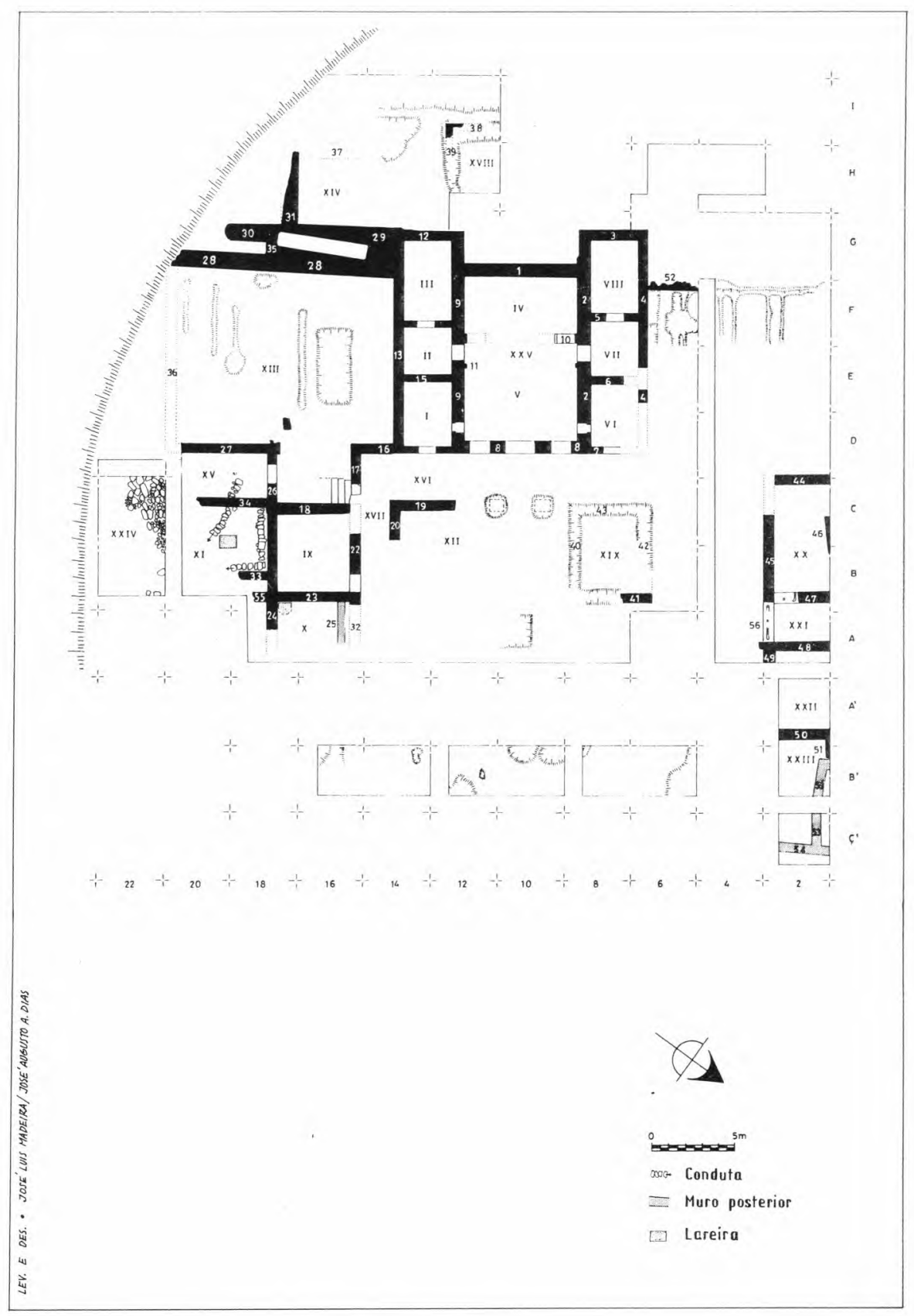

FIG. 1 - Planta das estruturas, após as escavações de 1994 


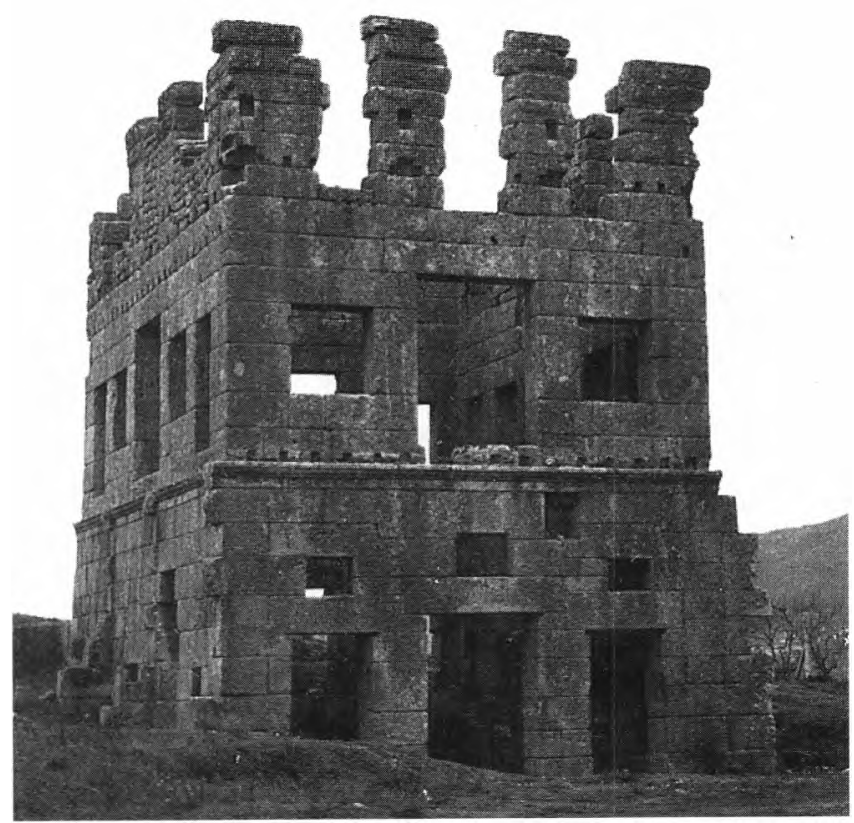

Fото 1 - A Torre de Centum Celas em 1993, antes do início das escavações

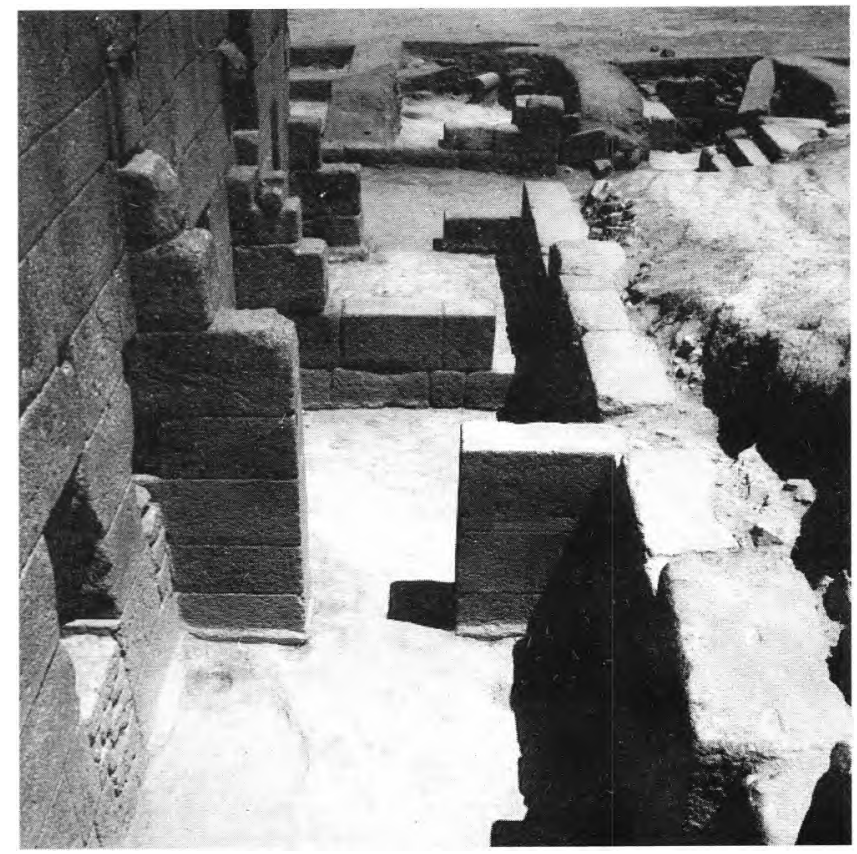

FoTo 2 - Salas III, II e I, após a escavação 


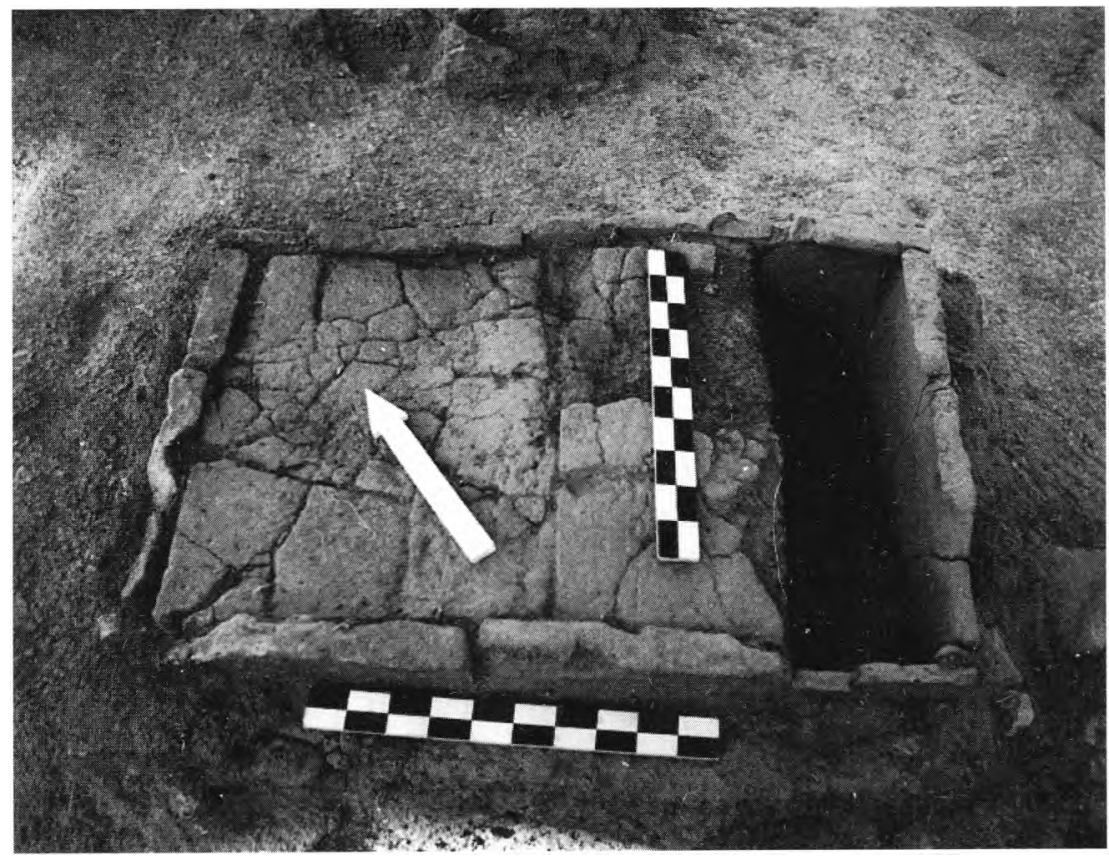

Foто 3 - Lareira da sala XI

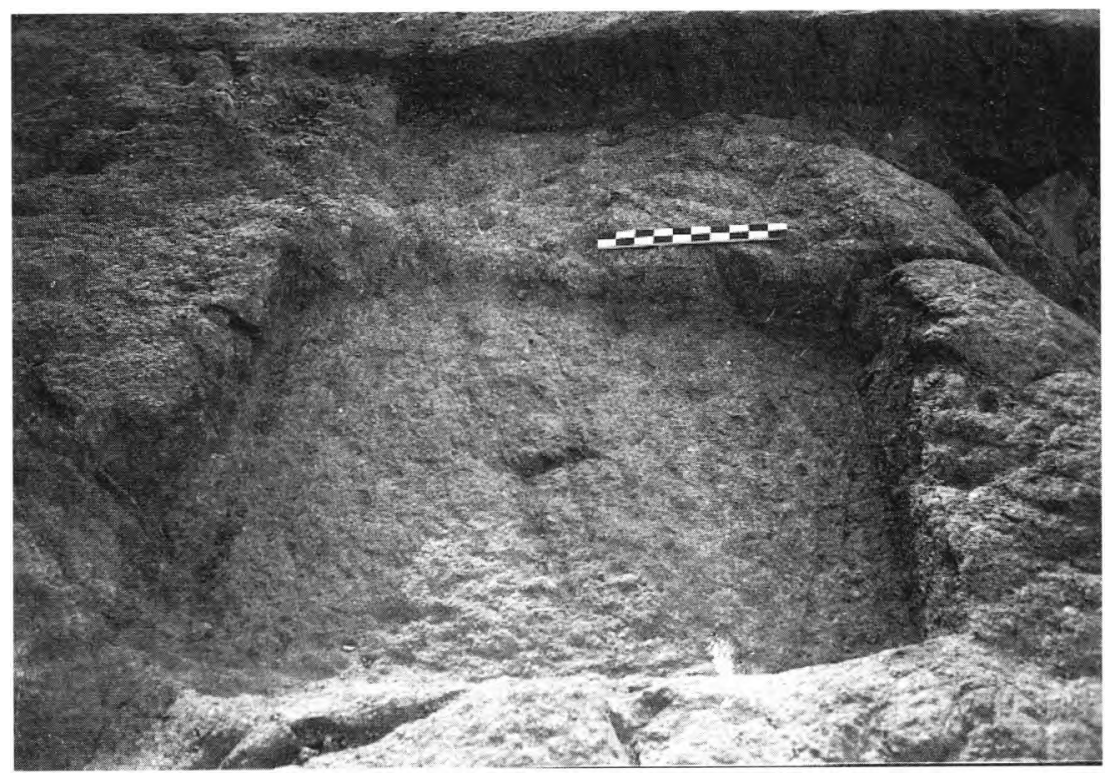

Fото 4 - Aspecto de um dos alicerces das pilastras, para suporte do varandim 


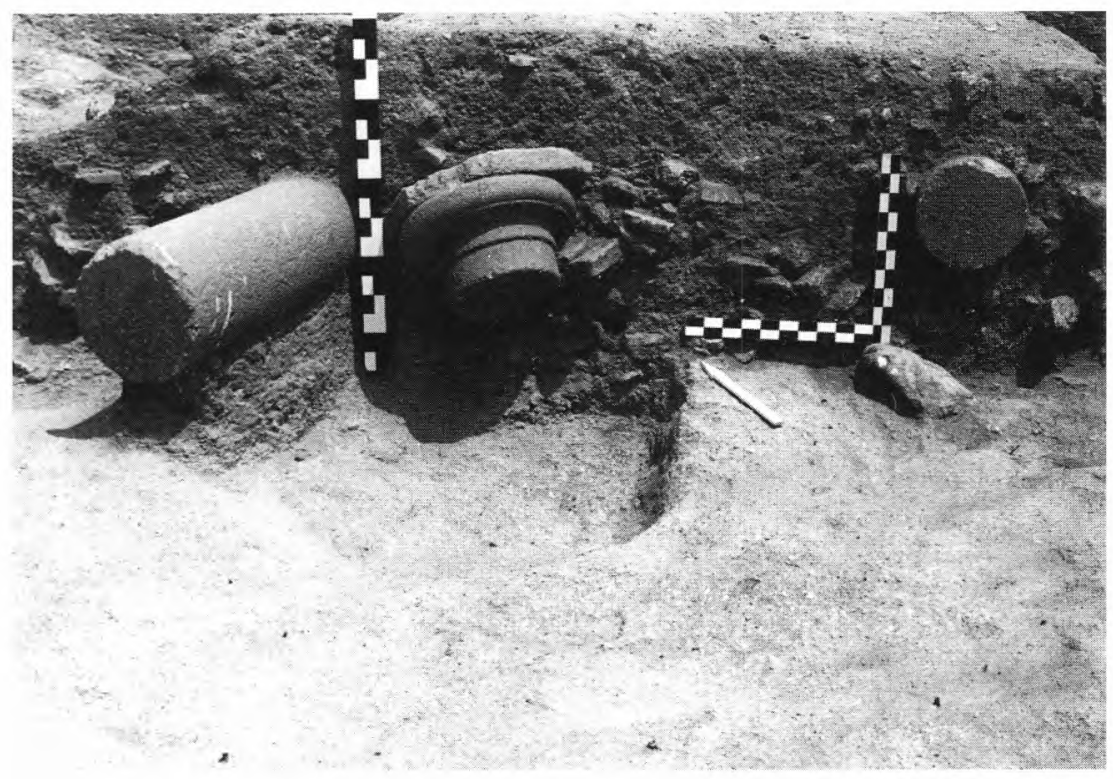

Foto 5 - Fustes e capitel toscano, no meio da camada de destruição datada do séc. Ili 


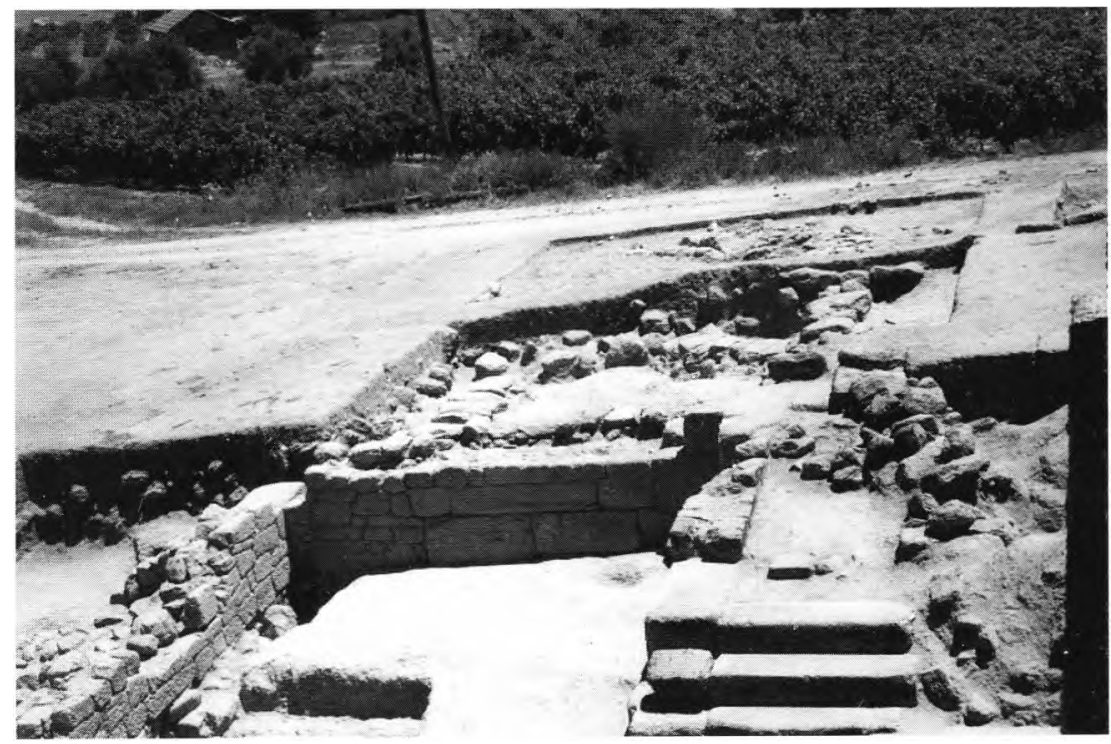

Fото 6 - Vista da parte Nascente, vendo-se em $1 .^{\circ}$ plano a sala IX e as escadas de acesso ao varandim do $1 .^{\circ}$ andar

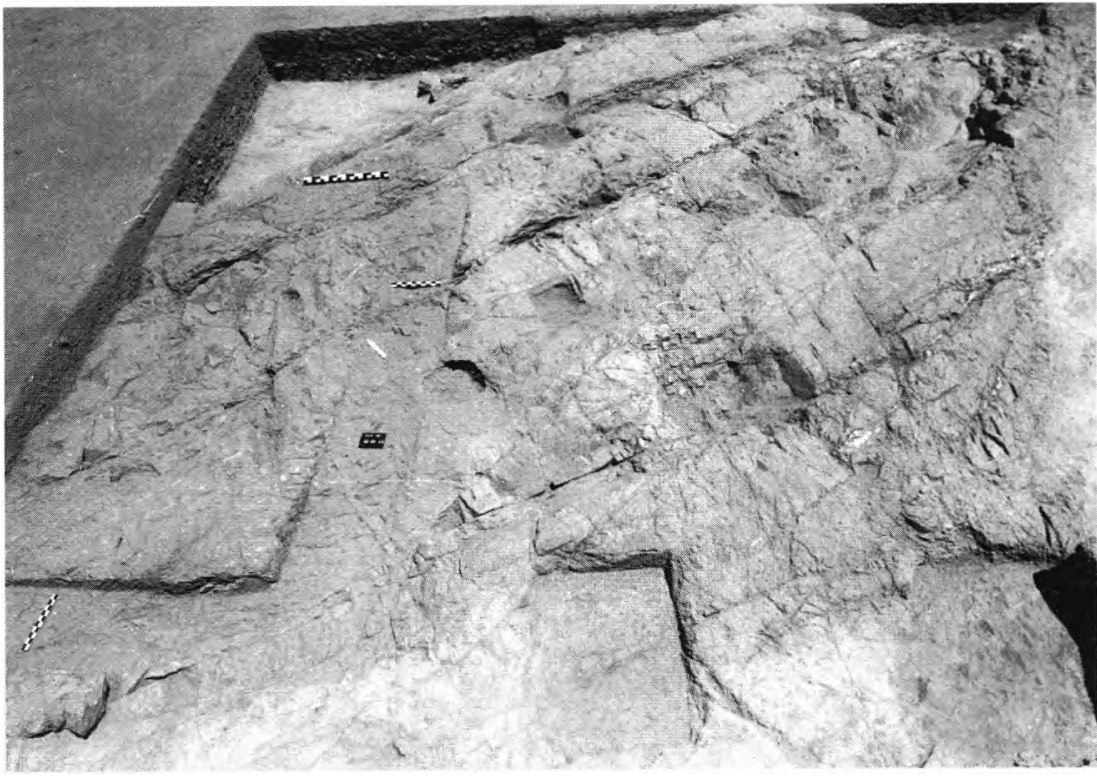

Fото 7 - Pormenor das estruturas postas a descoberto na parte Norte da Torre: fundações das duas pilastras do varandim e de parte da sala XIX 


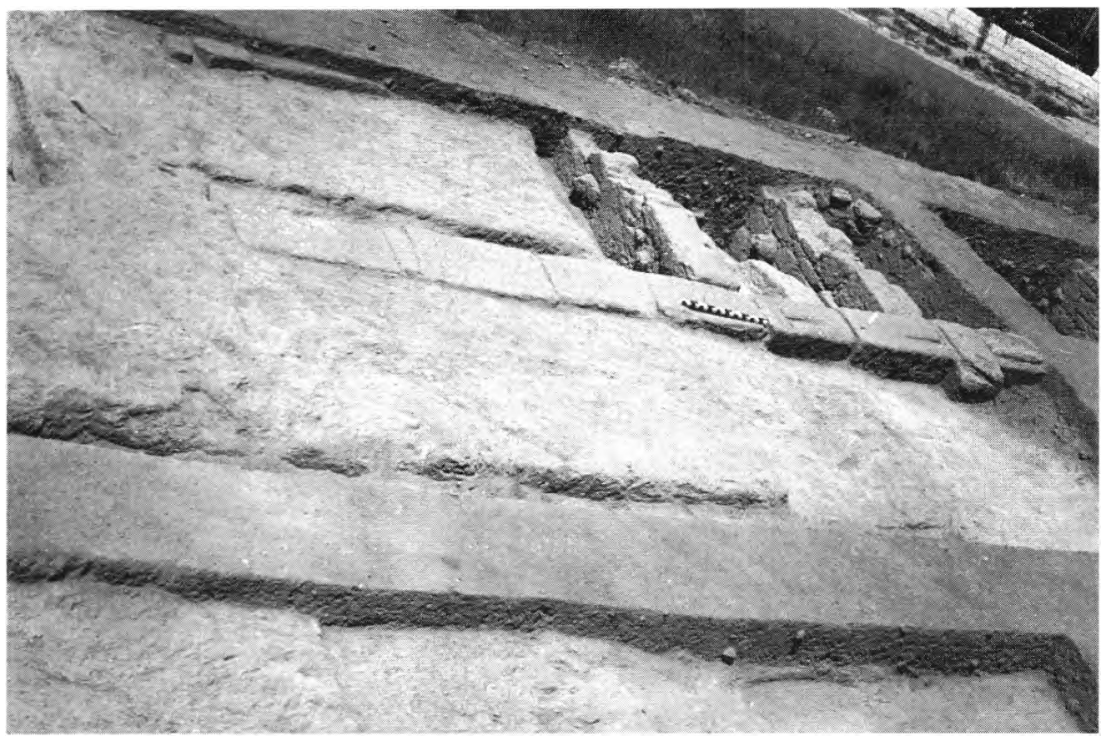

FOTо 8 - Aspecto dos muros e soleiras postas a descoberto na parte Noroeste da Torre

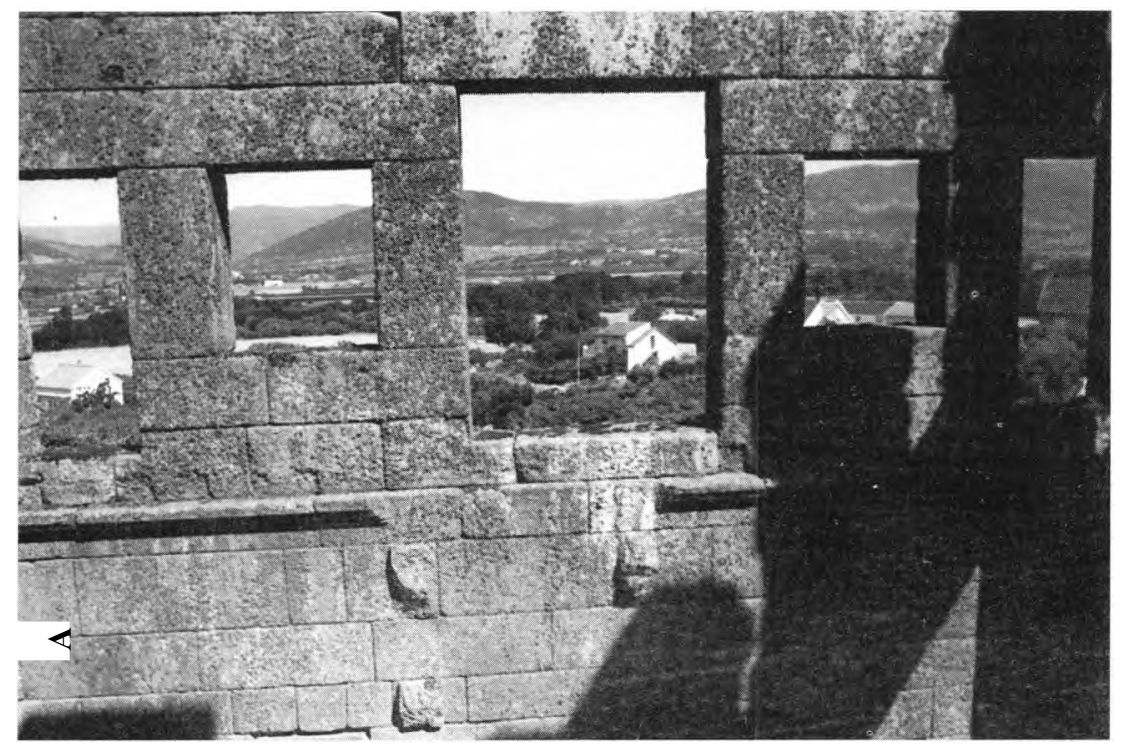

FOTO 9 - Parede interior da Torre, vendo os arranques dos muros 10 e 11, bem como os encaixes dos caibros de madeira que suportavam o pavimento 


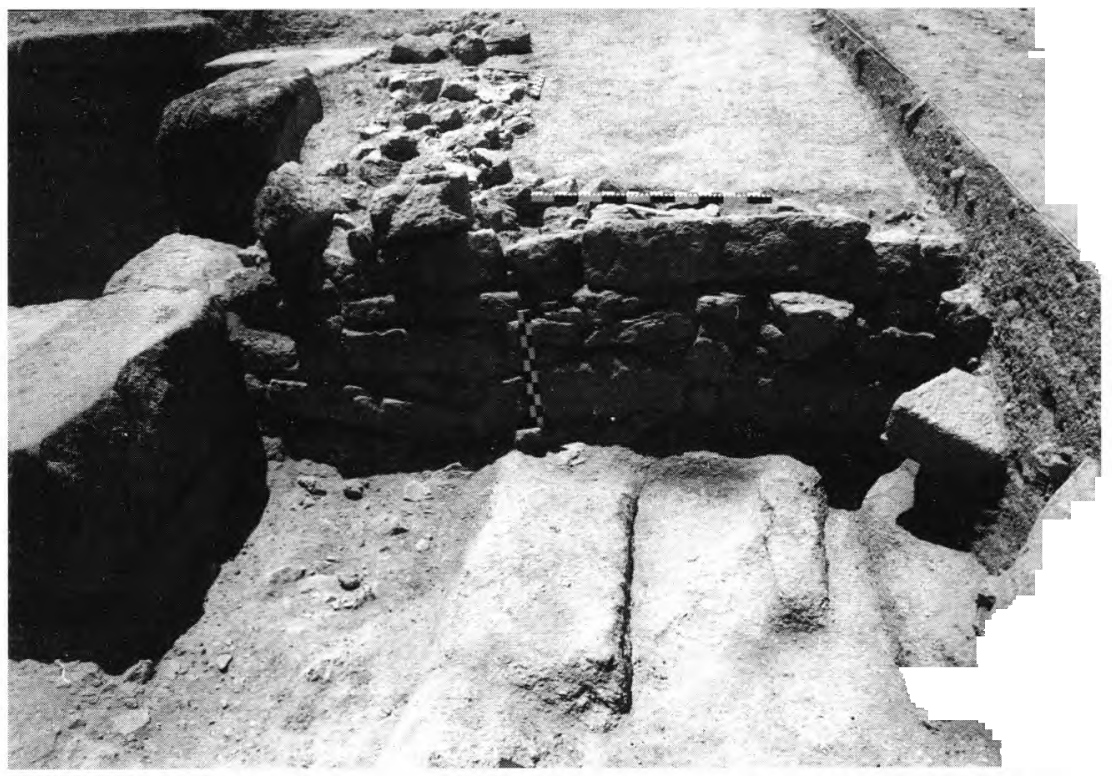

FOTо 10 - Aspecto da parede 52, vendo-se os rasgos no solo de base

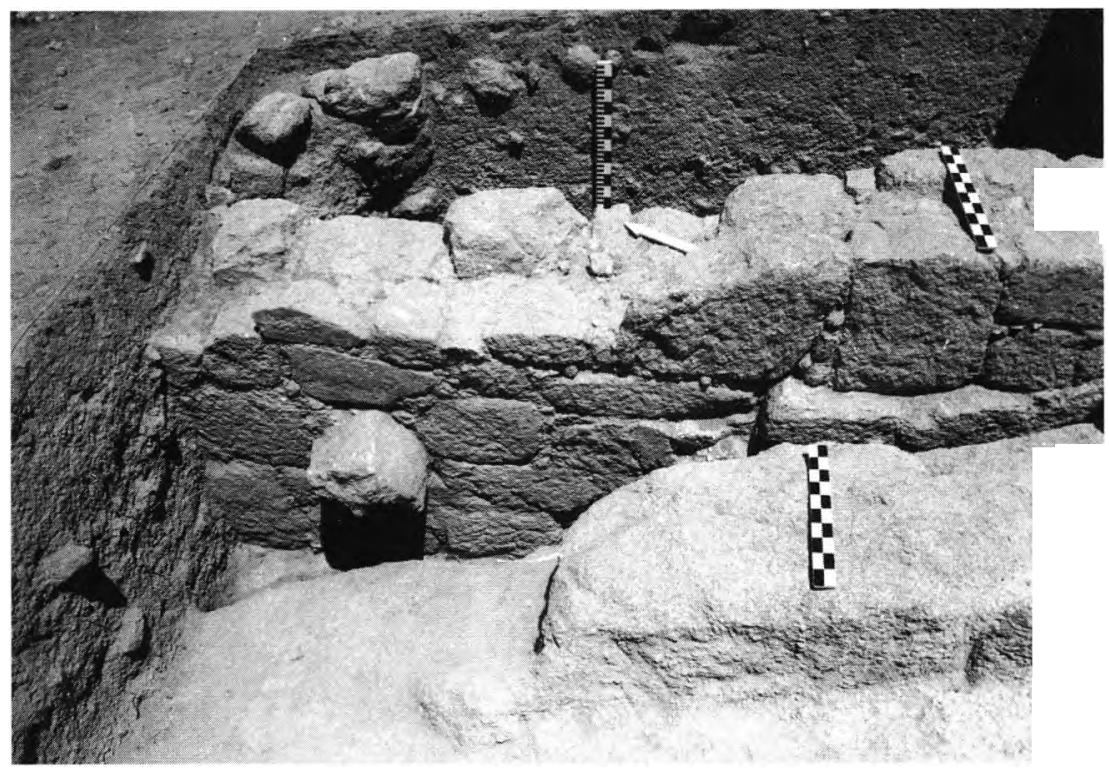

FOTо 11 - Pormenor da técnica construtiva do muro 48 


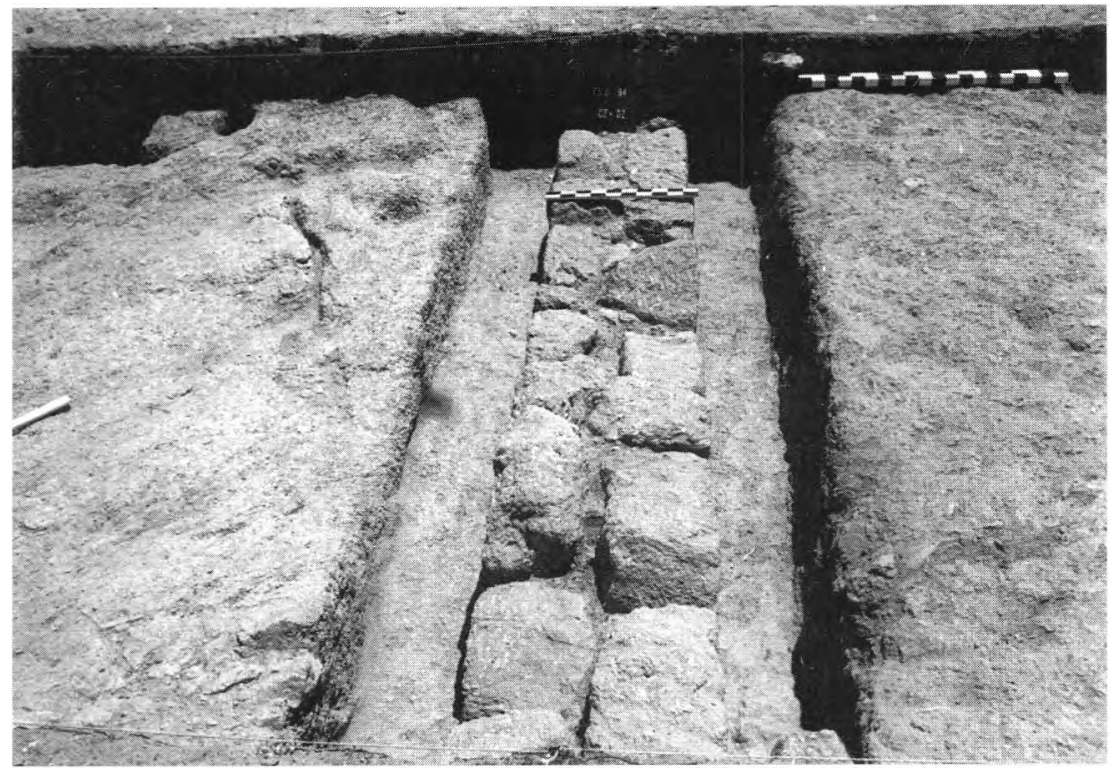

Fото 12 - Muro 46, inserido no meio de uma vala aberta no afloramento granítico, e posteriormente cheia com areão

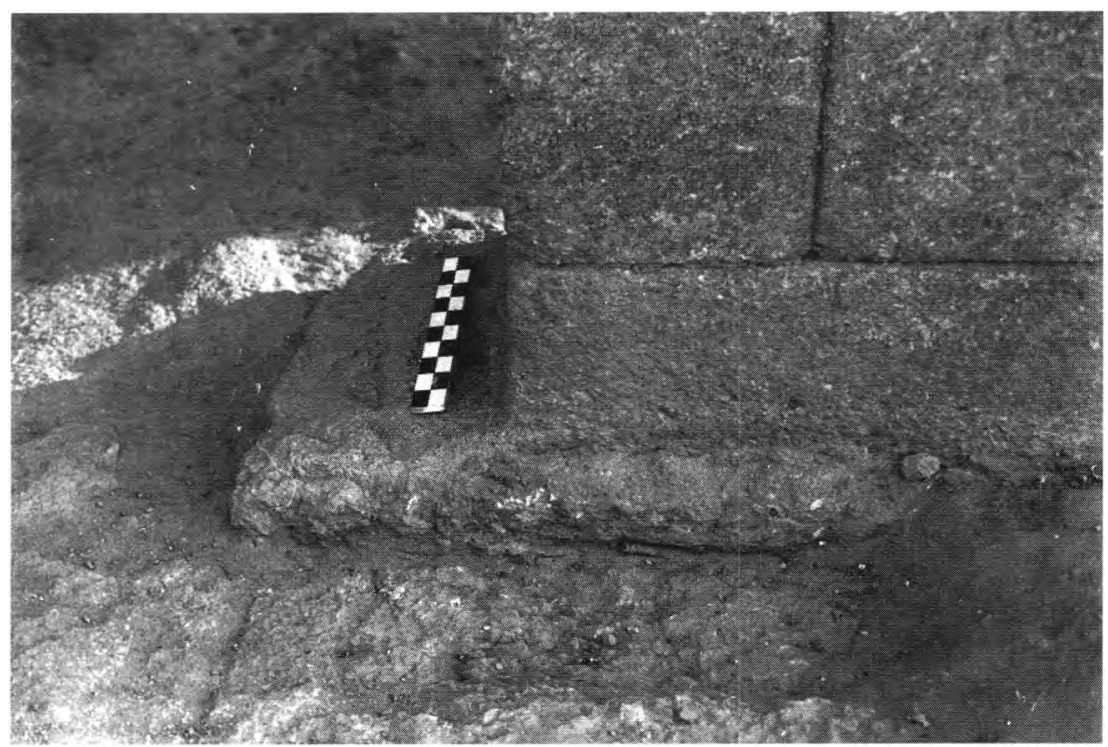

FOто 13 - Pormenor do assentamento de uma das pedras de fundação da parede 8 


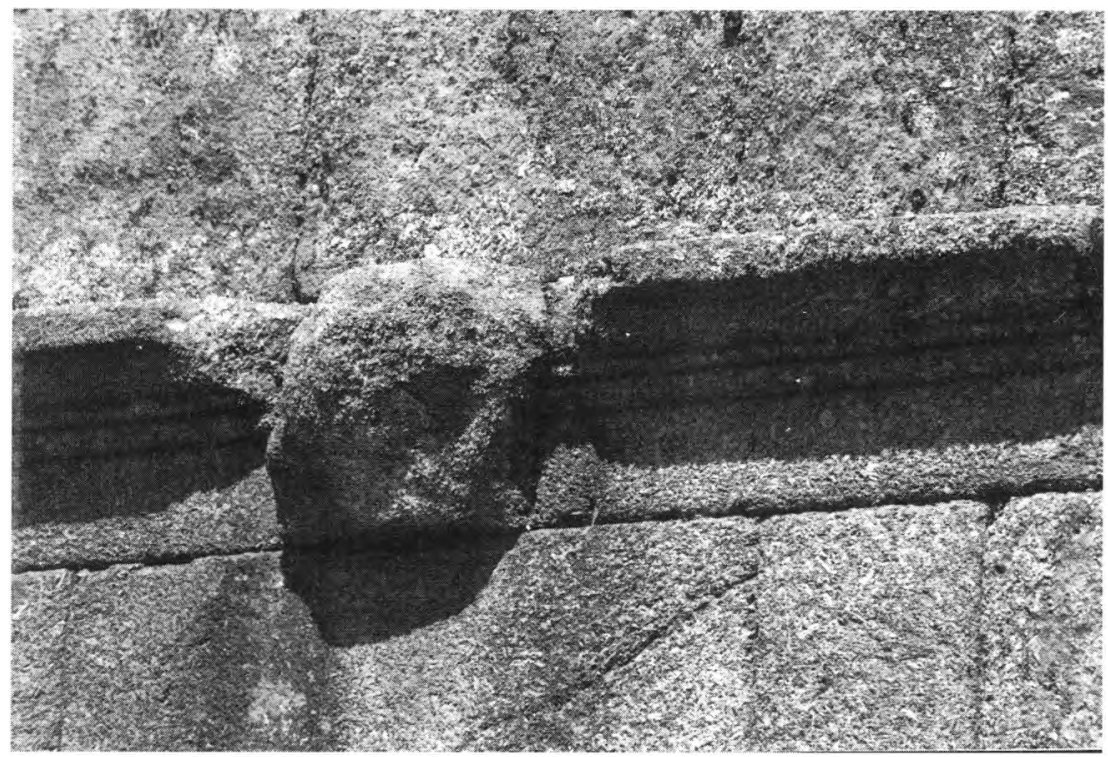

FOTo 14 - Friso e arranque de parede com friso, ao nível do $1 .^{\circ}$ andar

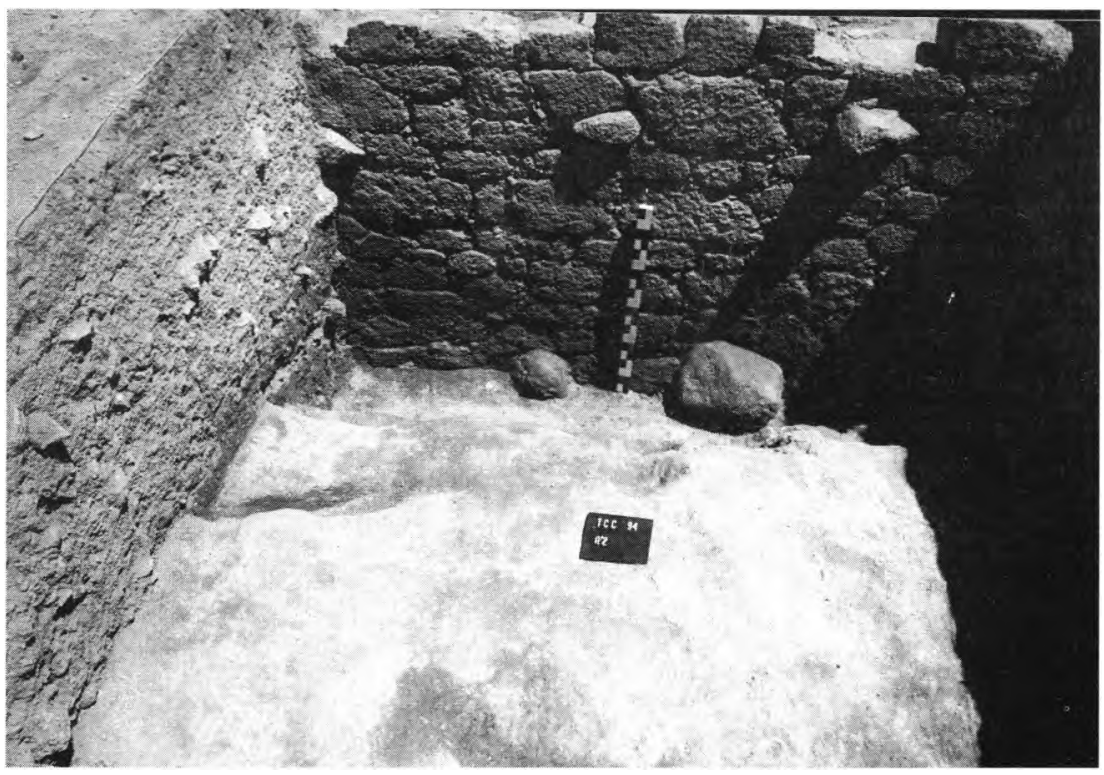

Fото 15 - Aparelho de uma das paredes postas a descoberto a Noroeste da Torre 